\title{
The effectiveness of cognitive- behavioral based art therapy approach on the self-concept, body image in adolescent girls with body dysmorphic disorder in Ahvaz city
}

\author{
Ahlam Jassemi Zargani ${ }^{1}$, Reza Johari Fard ${ }^{2}$ \\ 1-Master of clinical psychology, Islamic A zad University of Ahvaz, Ahvaz, Iran. ORCID: 0000-0002-2858-0727 \\ 2-Assistant professor, Department of clinical psychology, Islamic Azad University of Ahvaz, Ahvaz, Iran \\ (Corresponding Author). ORCID: 0000- 0003-0505-0501Ｅ-mail: rjoharifard@g mail.com
}

Received: 25/09/2018

Accepted: 28/01/2019

\begin{abstract}
Introduction: Body dysmorphic disorder is one of the common adolescence disorders which is characterized by mental occupation with bodily deficits.

Aim: The overall aim of this study was to determine the effectiveness of cognitive-behavioral art therapy on the self-concept, body image in adolescent girls suffering from body dysmorphic disorder in Ahvaz city.

Method: The sample consisted of 30 students (15 in the experimental group and 15 in the control group) from the students who were selected by convenience sampling. The research method was quasi-experimental with pre-test, post-test, and follow-up and with the control group. For data collection, Yale-Brown obssesive compulsive scale and Self-concept questionnaire, multidimensional body- self relashionship questionnaire were used.

Results: To analyze data, multivariate covariance analysis and SPSS16 software were used. Data results analysis indicated that cognitive-behavioral based art therapy in the experimental group compared with the control increased self-concept and body image and this effect continued during the follow- up phase.

Conclusion: Therefore, it can be concluded that principles of art therapy based on cognitivebehavioral therapy can be used in the treatment of people with abdominal disorder.
\end{abstract}

Keywords: Art therapy, Cognitive-behavioral therapy, Self-concept, Body image, Body dysmorphic disorder

How to cite this article : Jassemi Zargani A, Johari Fard R. The effectiveness of cognitive- behavioral based art therapy approach on the selfconcept, body image in adolescent girls with body dysmorphic disorder in Ahvaz city. Shenakht Journal of Psychology and Psychiatry. 2019; 6 (1): 11-22.URL :http://shenakht.muk.ac.ir/article-1-529-fa.pdf

Copyright (C) 2018 the Author (s). Published by Kurdistan University of Medical Sciences. This is an open access article distributed under the terms of the Creative Commons Attribution-Non Commercial License 4.0 (CCBY-NC), where it is permissible to download, share, remix, transform, and buildup the work provided it is properly cited. The work cannot be used commercially without permission from the journal. 


\title{
اثربخشى هنر در مانى مبتنى بر رويكرد شناختى- رفتارى بر خودينداره و تنانكاره

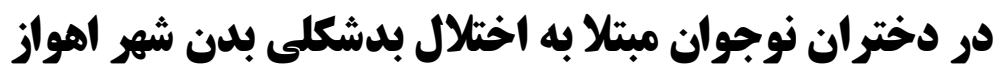

\author{
احلام جاسمى زركانى '، رضا جوهرى فرد' \\ ا. ا.كارشناسى ارشد روانشناسى بالينى، دانشكاه آزاد اسلامى واحد اهواز، اهواز، ايران. إنان.

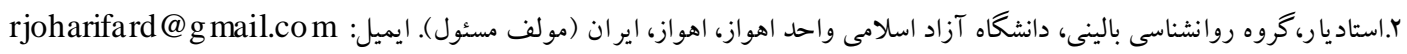

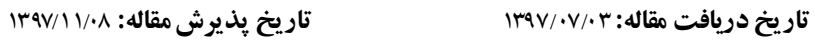

جكيده

مقدمه: اختلال بدشكلى بدن يكى از اختلالات شايع دوران نوجوانى است كه با اشتغال ذهنى به وجود نقص جسمانى در بدن مشخص مىشود. هدف: هدف كلى اين بُزوهش تعيين اثربخشى هنردرمانى مبتى بر رويكرد شناختى -رفتارى بر خودينداره و تن انگاره در دختران نوجوان مبتلا به اختلال بدشكلى بدن شهر اهواز بود. روش: نمونه يُوهش شامل ·r نفر (ها نفر گروه آزمايش و ها نفر گروه كنترل) از دانش آموزان بود كه به صورت نمونه كيرى در

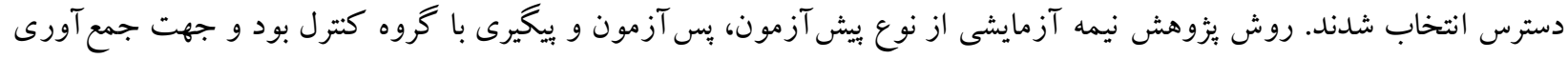

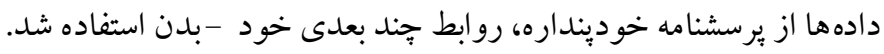

يافتهها: براى تحليل دادهها از روش تحليل كواريانس جند متغيرى و نرم افزار 19 SPSS استفاده شد. نتايج حاصل از تحليل دادهها

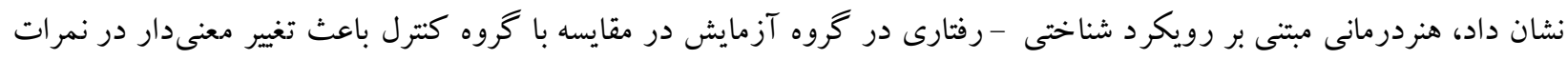

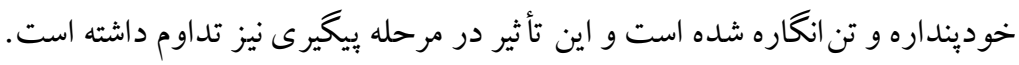

نتيجه كيرى: بنابراين مى توان نتيجه گرفت كه هنردرمانى مبتى بر اصول درمان شناختى رفتارى مىتواند در درمان افراد مبتلا به اختلال بدشكلى بدن مورد استفاده قرار بكيرد. كليدوازه ها: هنردرمانى، درمان شناختى - رفتارى، خودينداره، تن انگاره، اختلال بدشكلى بدن 


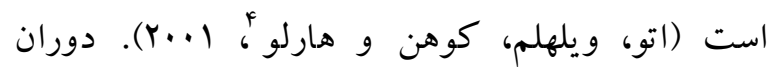
مقدمه نوجو انى با ويزّكى هاى جسمانى، روانشناختى، هيجانى و تغييرات اجتماعى مشخص مىشود. اطلاعات مربوط به بدن، در بيشتر نو جوانان نشان از عدم رضايت آنهاست.

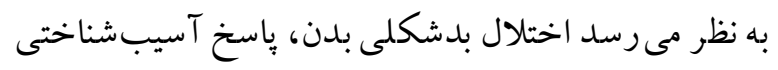
به تغييرات جسمانى و هورمونى است كه در طى بلوغ

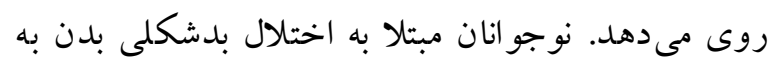
طور مكرر ساعتى را جلوى آينه مى ايستند و به وارسى و و وهيه

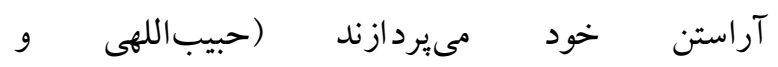

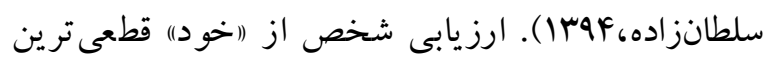
عامل در روند رشد روانى است كه تماماً به شيوه آكاهانه و صريح و شفاهى يا بر شمردن صفات و توصيف حالات

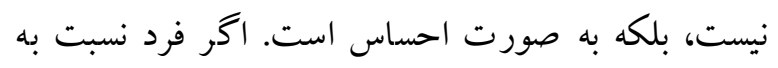

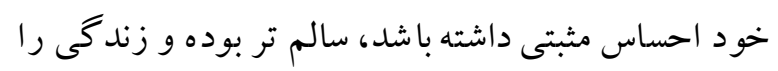

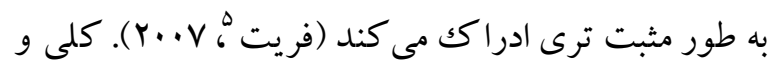
مارتين (Y.|F)، در ئزوهشى نشان دادند افراد داراى اختلال بدشكلى بدن شناختها و احساسات منفى در مورد ظاهر را بيشتر از گروه كنترل داشتند.

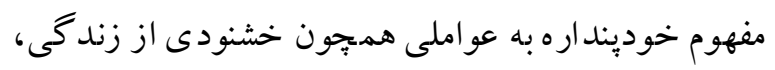
علاقه به خود و خود ارزشمندى مرتبط است كه به

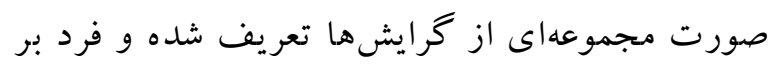
اساس آنها نخرش و رفتارهاى خود را توصيف و ارزيابى

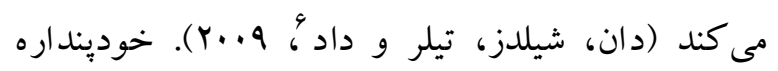
تصويرى است كه ما از خود داريم. اين تصوير به طرق مختلف از جمله تعامل با ديخران شكل مى گيرد (ياسترينو

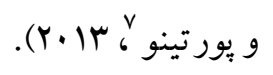

${ }^{4}$. Otto, Wilhelm, Cohen\& Harlow

5 . Freeth

6. Dunn, Shields, Taylor\& Dodd

7. Pastorino\& Portillo
يكى از مسائلى كه امروزه اهميت فراوانى يافته زيبايى دوستى و زيبايى طلبى است كه بيشتر ناشى از تغييرات فرهنگى، ارزشى و تبليغات رسانه ها و فضاى مجازى است

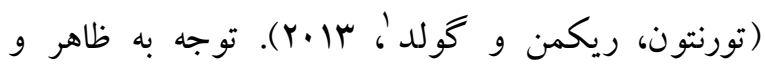
متناسب بودن در هر دورهاى وجود دارد گاهى اين توجه به صورت افراطى و حساسيت شديد ظهور بيدا مى كند كه ديخر طبيعى نبوده و تبديل به اختلال بدشكلى بدن مى گردد و عملكرد فردى و اجتماعى افراد را تحت تأثير

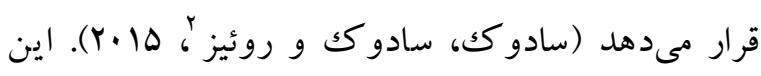
اختلال با اشتغال ذهنى شديد به يكك نقص يا عيب ناجيز و حس فرضى در ظاهر فرد مشخص مىشود (بوهلمن،

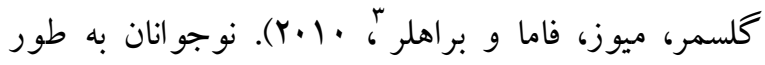
طبيعى روى جنبهاى ظاهرى خود حساسيت ويزهاى دارند و ديدشان راجع به ظاهرشان با رضايت از خود

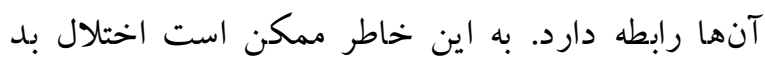
شكلى بدن با رضايت طبيعى از خود، در آنها اشتباه كرفته شود (شيخى، حافظ نيا، كارگرى و مسعودى،

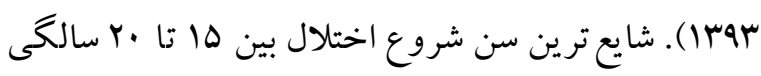
است (اثنى عشرى و همكاران، سوسب). ميز ان شيوع اختلال بدشكلى بدن، در عموم مردم حدود V درصد گزارش شده است كه با توجه به شيوع بالاى انواع جراحى هاى ترميمى در افراد مبتلا به اختلال بدشكلى بدن و تلاش هاى

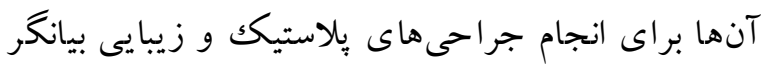
نارضايتى آنها از ظاهر جسمانىشان است. شيوع اختلال بدشكلى بدن در جمعيتهاى انتخابى مانند كلينيككاى يوست، داخلمى و جراحى زيبايى بالاتر از جمعيت عمو مى ليى

\footnotetext{
1. Thornton, Ryckman \& gold

. Sadock, Sadock \& Ruiz

. Bohlmann, Glaesmer, Mewes, Fama\& Brahler
} 
نااميدى، ترس و تنهايىاى را كه اين قبيل تجارب ممكن

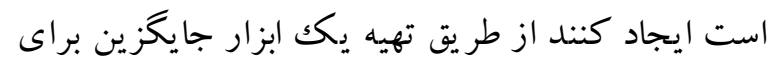
شرح احساسات و ايجاد ارتباط جهت رساندن و فهماندن

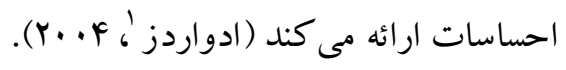
افراد تحت فشارهاى اجتماعى، فرهنگى و انواع تبليغات رسانه ها بر زيبايى و تناسب اندام به قبول و يذيرش نوعى إنى از معيار ايده آل وادار مى شوند، در اين نظام شكل بدنى و وليى بنابر اين لباسهاى مختلف روز به روز متفاوت مىشوند و به تبع آن فرد به طور مداوم در حال ارزيابى ظاهر و تناسب اندام خود مى شود و رضايت كافى، در مقايسه با اندام و ورد تناسب ايده آلى كه جامعه بر وى تحميل كرده است،

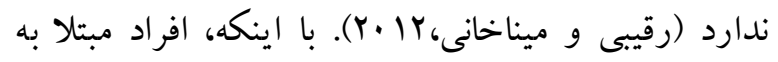
اختلال بدشكلى بدن نقص ندارند يا اخر نقصى هم دارند خيلى جزئى است اين افراد فكر مى كنند كه نقص آنها خيلى بارز و براى ديخران روشن و قابل رؤيت است است استى (حبيب اللهى و سلطان زاده، نوجو انى با توجه به تحولات جسمانى مرتبط با دوران

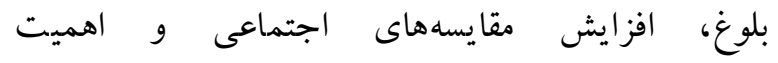

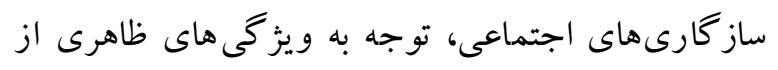
اهميت خاصى بر خوردار مى شود (احمد و باقرى، بهr I) ). همين طور كه انسان از طفوليت به سمت بلوغ ييش مىرود

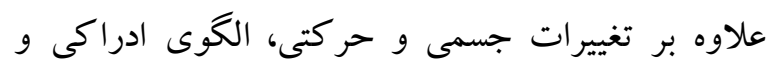
خوديند اره انسان شكل مى گير د اين الكوى ادراكى باعث مى شود كه فرد هميشه در ذهن خود در حال مقايسه خود با ديخران باشد و شكل خود را در ذهن تصور و مرور كند (قدوسى تبار، صدرى، زينعلى و صحراوى، Y +r). از طرفى ايجاد احساس كهترى به دليل ظاهر و يا تجربه تمسخر آميز از سوى ديخران مى تواند فرد را در مقابل
يكى از جنبههاى مهم تصوير خود كه در موقعيتهاى اجتماعى ظهور مى يابد تن انگًاره افراد است كه اشاره به افكار، اعتقادات، احساسات و رفتارهاى مرتبط با بدن ادراكك شده دارد (موسوى و همكاران، هوسا). تن انگاره در نوجوانان سازهاى قدرتمند است كه مىتو اند بر رفتار تأثير بحذارد. در جامعهى معاصر، زيبايى و اهميت بدن عاملى است كه نوجو انان را به سوى نارضايتى از ظاهر سوق مىدهد. تداخل نكرانى درباره ظاهر، در عملكرد اجتماعى فرد زمانى اتفاق مىافتد كه ظاهر فرد براى او آنقدر اهميت بيدا كند كه عملكرد و روابط اجتماعى او را تحت تأثير قرار دهد (اسدى گندمانى و تيمور زاده،

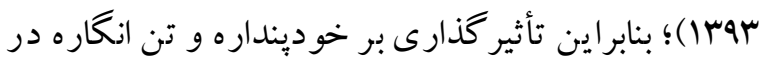
اين نو جوانان مىتواند در درمان اختلال بدشكلى بدن مؤثر باشد. يكى از رويكردهاى درمانى كه مىتواند در اين زمينه مورد استفاده قرار بكيرد هنردرمانى است. اثربخشى هنر درمانى بر شاخصهاى روانى در يزوهش هاى قبلى نشان داده شده است. به عنوان مثال زارع زاده

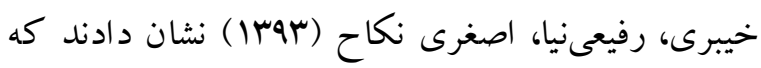
هنر درمانى گروهى بر افزايش مؤلفهاى رفتارى و و

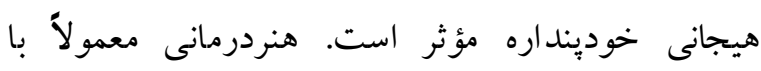

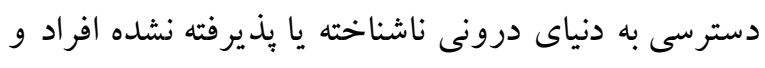
راههايى كه روابط دنياى بيرونى را تحت تأثير قرار مىدهد سرو كار دارد. در اين روش ممكن است كه تعارض ها و احساسات سر كوب شده، بيان شوند. با ظهور تجارب درونى در فضاى امنى كه هنر درمانگر ايجاد مى كند، فرد فرصت افزايش خود ادراكى را بيدا مى كند و از طريق برونىسازى تجربيات درونى، از آنها دور

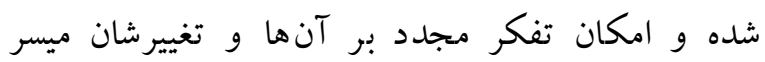
مىشود. در اين جاست كه هنر درمانى شيوهاى غلبه بر

1. Edwards 
فرهنكى ايرانى همخوانى بيشترى داشته باشد

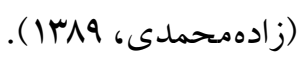
رويكردى كه در اجراى هنر درمانى اين ئوهش مورد

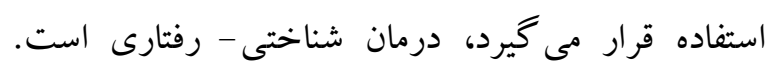
رويكردى كوتاهمدت و معطوف به زمان حال كه شايستكىهاى رفتارى و شناختى را كه فرد براى عملكرد ساز گارانه در دنياى درون فردى و بين فردى نياز دارد، ردئ آموزش مى دهد (جوهرىفرد، بوسا ). يُزوهش هايى مانند

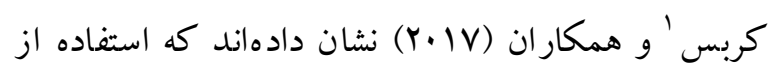
اصول درمان شناختى رفتارى مى تو اند در كاهش علائم

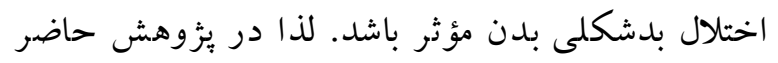

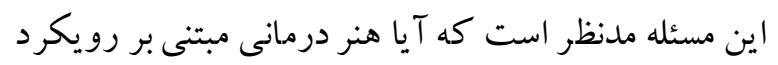

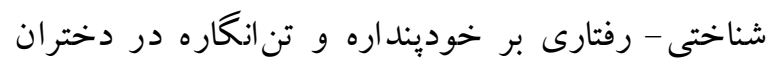
نو جوان مبتلا به اختلال بدشكلى بدن اثر دارد؟ بـ بـ

روش جامعه آمارى در اين ئزوهش شامل كليه دانش آموزان دختر نو جوان مبتلا به اختلال بدشكلى بدن دوره دوم متوسطه 19-19 سال شهر اهواز در سال تحصيلى

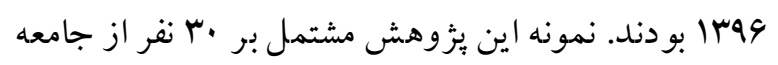
مذكور بود كه براى انتخاب آنها از روش نمونه گيرى در برد

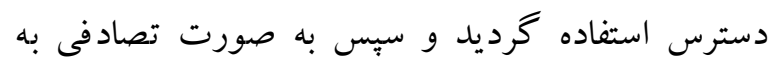
كمكك قرعه كشى در دو گروه (ها نفر كروه آزمايش و و

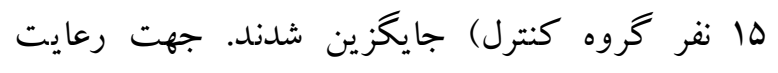
اصول اخلاقى ئزوهش توضيحات لازم در زمينه مداخله به آزمودنىها داده شد و آزمودنىها بِس از امضاى بروس

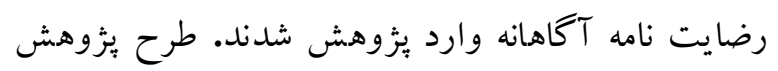
از نوع شبه تجربى با يك گرووه هنر درمانى مبتنى بر
تن انگاره خود حساس نمايد (خانجانى، بابايور و صبا، | (1/1). هنر دريجهاى به روان آدمى مى گشايد، باعث مىشود انسان از آن يس خود را به گونهاى متفاوت بشناسد. انجام دادن فعاليتهاى هنرى به افراد كمكك مى كند تا احساسات و هيجانات را كه نمى تو انند با رفتار و كفتار نشان دهند، هر طور كه مى خواهند به شكل بهترى با ديخران در ميان بـذارند و بر ترس هايشان غلبه كنند (فولادوند، به نقل از اسمعيل طلايى، اجس||). هنردرمانى روشى است كه به افراد كمك مى كند تا با بهره گيرى از

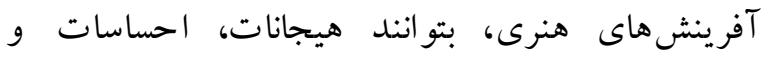
تعارضهاى درونى خود را ابراز كنند. آثار هنرى بديد آمده، بيان آزادانهاى از هيجانات و احساسات درونى، خاطرات و تجربيات گذشته، تمايلات قلبى و رؤياهاى فرد است. هنگًامى كه اثرى به بايان مىرسد، رنگكها، نمادها و ساختارها به قدرى شاخص هستند كه به فرد كمك كنند در راه شناخت خود كام بر دارد (مهدوى، به نقل از مير فخر رجائى، (1) إب). در بعضى از رويكردهاى هنر درمانى مانند شناختى - رفتارى تكليف هم وجود دارد. هدف از تكليف خانكى برقرارى ارتباط درمانى و تكميل فعاليتهاى درمانى انجام شده است تا فرد بيوستكى و دلبستكى خود را با درمان حفظ كند و ورماني

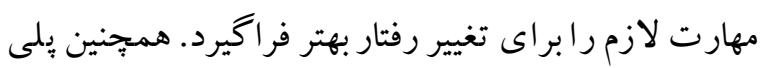
است كه جلسات متوالى را به همديخر مرتبط كند و

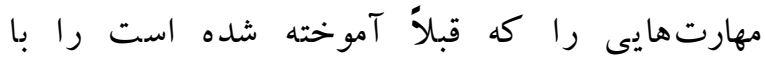
ياد كيرىهاى تازه تركيب كند. هنر درمانى شناختى رفتارى از روشهاى كوتاه مدت و ساختار مدار است كه امكان استفاده واقعىترى از آن وجود دارد. در اين روش از اصول تقويت منفى و مثبت بيشتر مىتوان استفاده كرد و فعاليت و تكليف و تمرين تعيين كرد كه با موقعيت

\footnotetext{
1. Krebs
} 
انتظار براى آموزش قرار گرفت. برنامه درمانى بر اساس

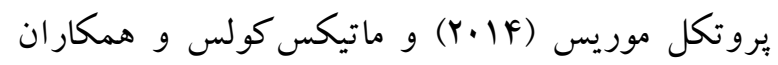

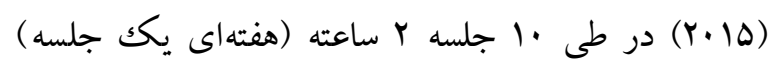
برغزار شد. داده هاى جمع آورىشده با روش تحليل كوواريانس جندمتغيرى و با استفاده از نرم افزار 19 SPSS خلاصه جلسات درمانى در جدول شماره ا ذكر شده

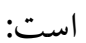

رويكرد شناختى - رفتارى بيش آزمون، ِس آزمون و بيخيرى اجرا شد. ملاككهاى ورود بيزوهش حاضر تشخيص اختلال بدشكلى بدن به عنو ان تشخيص اصلى، عدم همبودى با ساير اختلالات روانشناختى، داشتن سن ها و يا 19 سال و عدم رخدادهاى تنش زا در سه ماه كذشته بود. گرووه آزمايش با روش هنردرمانى مبتنى بر رويكرد شناختى رفتارى توسط متخصص روانشناسى بالينى كه داراى دكتراى تخصصى و مدركى دوره هنردرمانى بود. آموزش ديد و گروه كنترل در ليست ديت دراي

جدول 1 خلاصه جلسات درمانى

\begin{tabular}{|c|c|}
\hline شرح & جلسه \\
\hline معارفه و آشنايى بانوجوانان و آشناسازى آنها با روند كلى كار & جلسه اول \\
\hline با ابزار مورد علاقه به ترسيم جر خه تفكر نخر انى و بدشكلى خود مى يردازند. بر اي تكليف در منزل از آنها خواسته مى شود به ثبت گز ارش & جلسه دوم \\
\hline 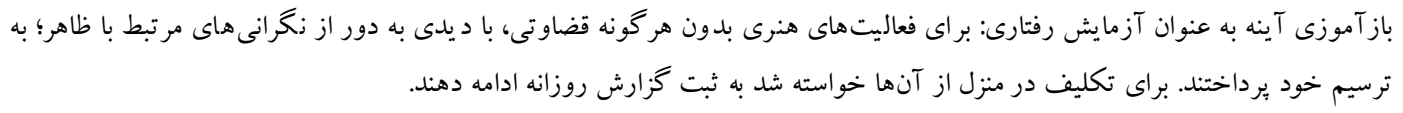 & جلسه \\
\hline 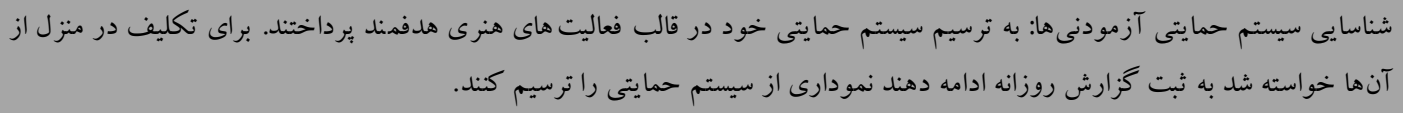 & جلسه ينجم \\
\hline
\end{tabular}

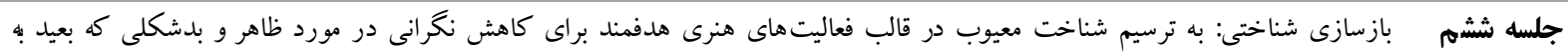

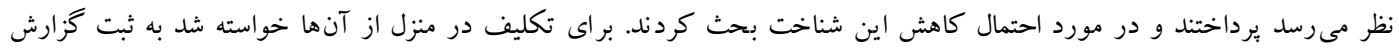
روزانه ادامه دهند و تصويرى كه احتمال تغيير آن شناخت را نشان مىدهد، ترسيم كنند.

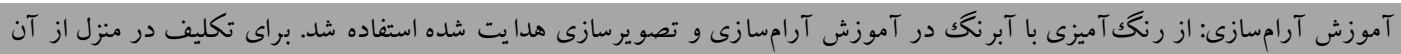

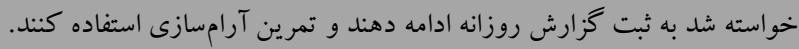

جلسه هشتم م مواجهه سازى خيالى از شرايط و فعاليتهاى مورد اجتناب: به ترسيم ضعيف ترين تا شديدترين و رتبه بندى نهايى از سه حالت اجتناب

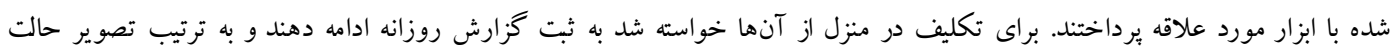
دوم و سوم را تكميل كنند. جلسه نهم مواجهه سازى واقعى با شرايط و فعاليتهاى مورد اجتناب: تسلط خود در مواجهه باضعيف ترين تا شديدترين حالت را با ابزار مورد علاقه

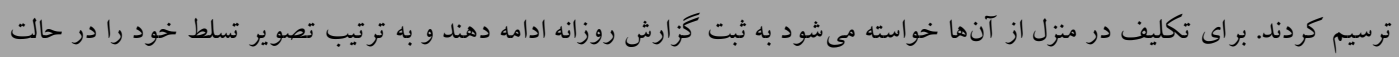
دوم و سوم تكميل كنند. بررسى بيشرفت و يِيشيرى از عود در آزمودنىها بود. ابتدا تمام تصاوير و بيشرفتى كه در آثار هنرى به وجود آمده مورد بحث و بررسى قرار گرفت؛ سيس نقاشى يل را كه نشاندهنده يِيشرفت به سوى اهدافشان است، ترسيم كردند. 
مفهومى را روى يكك مقياس دو قطبى V درجهاى علامت گذارى نمايد. جِنانجِه بِاسخ دهنده در اين مقياس

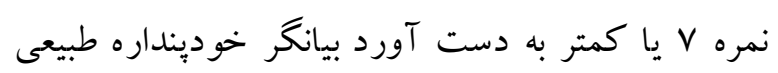
است اما اخر نمره بيشتر از V به دست آورد بيانگر خودينداره ضعيف و منفى است. خديوى و وكيلى إنى

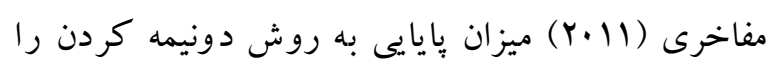
برابر 9V/ · به دست آوردند و روايى آزمون را نيز مورد

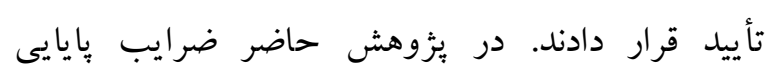
يرسشنامه با روش آلفاى كرونباخ •V/ • محاسبه كرديد. يرسشنامه روابط جند بعلدى خود -بلدن (MBSRQ): اين يرسشنامه به منظور ارزيابى تصوير بدنى فرد مورد استفاده

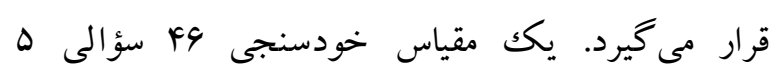

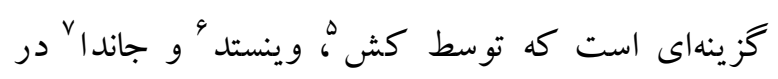
سالهاى 1919 و 191V ساخته شده است. خرده مقياسهاى اين برسشنامه عبارتاند از: () ارزيابى وضع

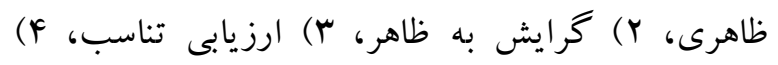
كرايش به تناسب، ه) دل مشغولى با اضافه وزن، وله رضايت از نواحى بدنى. در نسخه فارسى اين مقياس بـ باس ضريب آلفاى كرونباخ سؤالهاى هر يكك از خرده

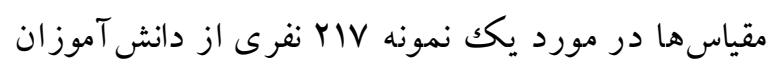

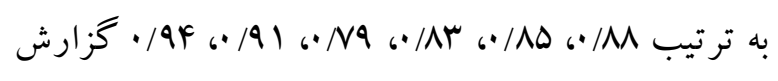
شده است (محموديان، ايبجى حق و و رسولز اده

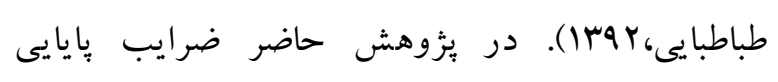
يرسشنامه با روش آلفاى كرونباخ سؤالهاى هر يكك از

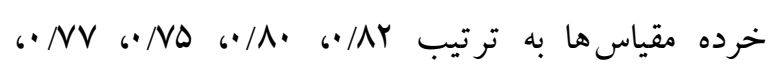

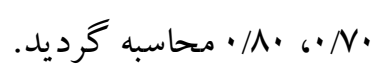

\section{يافته ها}

\footnotetext{
5 . Cash

6. Winsted

${ }^{7}$. Janda
}

ابزار آزمودنى ها قبل و بعد از مداخله و همجينين يكك ماه بِس

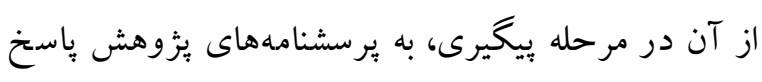
دادند كه عبارت بودند از:

يرسشنامه اصلاح شله، وسواس فكرى عملى بيل براون براى اختلال بلشكلى بلن (YBOCS- BDD): مقياس نوعى مصاحبه بالينى نيمه ساختار يافته است كه

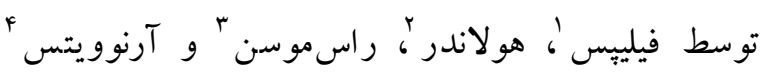

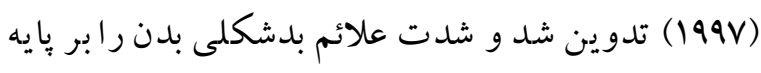
DSM - IV داراى rا سؤال است كه بِاسخ دهندكان ميزان توافق خود را يا هر كدام از ماده ها در مقياس ليكرت از دامنه

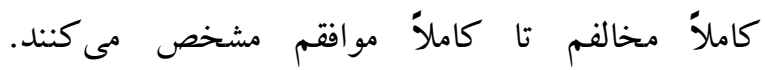

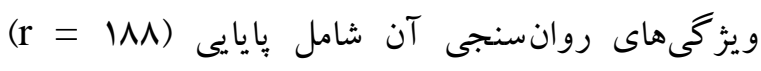
همسانى درونى ( • (Alpha = است. همجِنين روايى تشخيص آن در مقايسه با فرم درجه بندى شده كوتاه

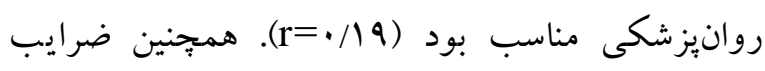
بايايى آن از نوع آلفاى كرونباخ، دو نيمه سازى و ضريب

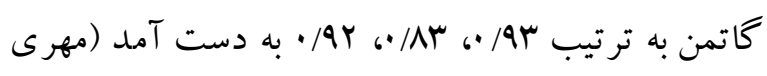

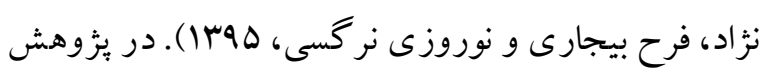
حاضر ضرايب پيايايى برسشنامه با روش آلفاى كرونباخ •^/ • محاسبه كرديد.

يرسشنامه خود ينداره راجرز (SCQ): اين برسشنامه توسط راجرز (1901) تهيه شده است و از دو فرم (الف) كه خود واقعى را مىسنجد و فرم (ب) كه خود آرمانى را مى سنجد، تشكيل شده است و هر فرم شامل ها سؤال است. در اين برسشنامه از آزمودنى خواسته مى شود تا ستر 


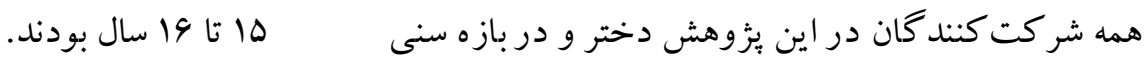

\begin{tabular}{|c|c|c|c|c|c|c|}
\hline \multicolumn{6}{|c|}{ خودينداره } & \\
\hline \multicolumn{2}{|c|}{ يِيكيرى } & \multicolumn{2}{|c|}{ يس آزمون } & \multicolumn{2}{|c|}{ يِي آزمون } & \\
\hline كنترل & آزمايش & كنترل & آزمايش & كنترل & آزمايش & \\
\hline $11 / 1$ & $\Delta M$ & $\mid r / r$. & $\Delta / 4 q$ & $1 Y / .9$ & $1 Y / 9$. & ميانكين \\
\hline$r / 9 Y$ & YMV & $r / r F$ & $r / \pi r$ & $r / T \Delta$ & r/To & انحراف \\
\hline \multicolumn{7}{|c|}{ تن ازعاره } \\
\hline$|F| / F$ & $\mid \mathrm{V} / / \mathrm{r}$ & $|F| / r$ & $|V| / r$ & $|F F| .9$ & $194 / 1$ & ميانكين \\
\hline $1 Y / 90$ & $11 / 19$ & $|F /| \mid$ & $11 / r$ & $14 / q 9$ & $10 / 01$ & انحراف \\
\hline
\end{tabular}

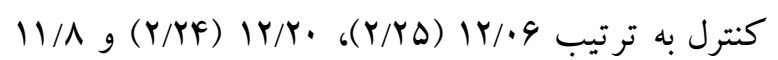

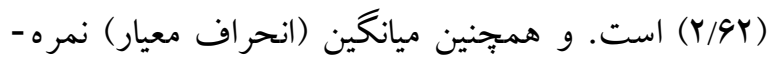

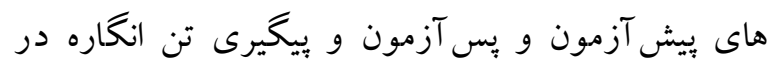

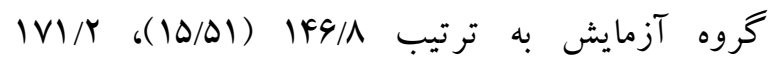

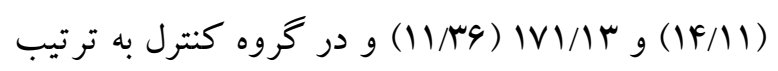

$(\mid Y / q 0)|F| / F,(|F /| I)|F| / Y$ ( $(\mid F / F q) \mid F F / . q$
بعد از اطمينان از محقق شدن بيشفرضهاى تحليل كوواريانس از اين روش جهت بررسى تأثير مداخله در

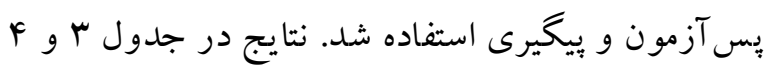

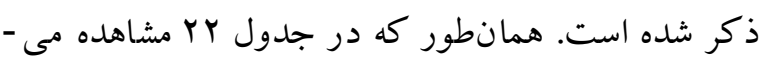

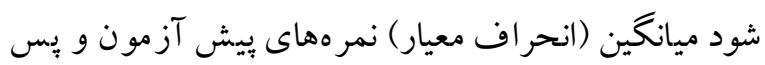
آزمون و يبيخيرى خودينداره در گرووه آزمايش به ترتيب .

جدول r نتايج تحليل كواريانس در مرحله بِّآزمون

\begin{tabular}{|c|c|c|c|c|c|c|}
\hline ضريب & معنى دارى سطح & $\mathbf{F}$ & مجذورات مينكين & درجه آزادى & مجذوروات & متغير وابسته \\
\hline - /A9. &.$/ \cdot 1$ & $10 r / 9 V q$ & $M T F / \Delta Q 1$ & 1 & $m / 891$ & خودينداره \\
\hline - $/ \mathrm{VAF}$ & $.1 . .1$ & $V G / \Delta F q$ & $9.99 / 999$ & 1 & $9.99 / 999$ & تن ازعاره \\
\hline
\end{tabular}

مبتنى بر رويكرد شناختى - رفتارى بر خودينداره و تن نتايج جدول شماره ب نشان مى دهد كه تحليل كوواريانس

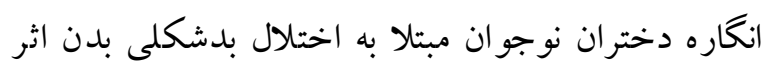
و F دارد. - مار. و $F=V F / D F q)$ هم در متغير تن انغاره

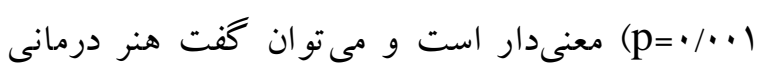




\begin{tabular}{|c|c|c|c|c|c|c|}
\hline \multicolumn{7}{|c|}{ جدول f نتايج تحليل كواريانس در مرحله ييگيرى } \\
\hline ضريب & معنى سطح & $\mathbf{F}$ & مجيانگين & درجه آزادى & مجذوروات & 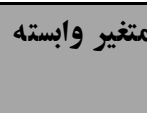 \\
\hline . / VAr &.$/ \cdot \cdot 1$ & $V Y / M V V$ & YMA/FGA & 1 & YMA/FGA & 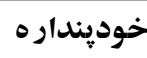 \\
\hline - N VEG &.$/ \cdot 1$ & $V / \Delta \Delta \Delta$ & $919 \Lambda / Y \cdot r$ & 1 & $919 \Lambda / Y . r$ & تن ازعاره \\
\hline
\end{tabular}

به اين درد و رنج عجيب، اختلال بدشكلى بدن مى گويند و محور آن، اشتغال ذهنى با يك نقص خيالى در ظاهر، ريخت و قيافه است، در حالى كه شخص ظاهرى عادى و

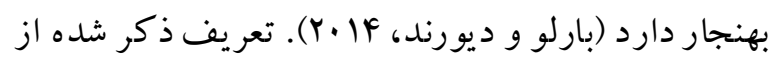
اختلال بدشكلى بدن نشان مىدهد كه اين اختلال ارتباط

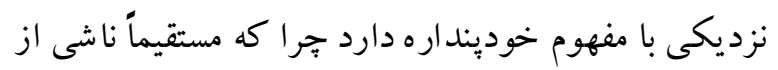
برداشت فرد نسبت به ظاهر خود است. خودينداره نيز شناختى است كه فرد از ويزگ لردا، اسناد، ظرفيتها، ارزش ها و ارتباطات خود دارد و به عنوان اطلاعات در

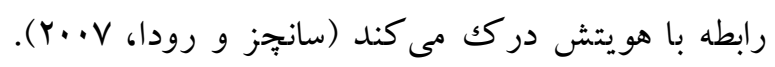
ينداره اين افراد نسبت به خود منفى است كه باعث ايجاد

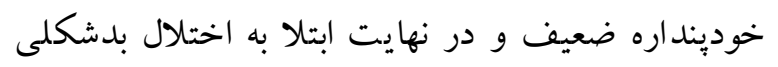
بدن در اين افراد شده است. هنر درمانى مبتنى بر رويكرد شناختى - رفتارى با استفاده از تكنيككهاى هنرى نخرش هاى مثبت، راههاى مقابله و مهارتهاى لازم براى بـ

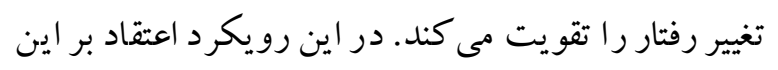

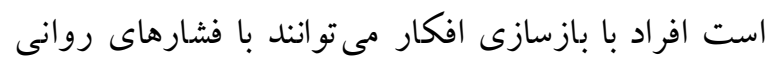
مقابله كنند در فرآيند درمان اين افكار كه منجر به ايجاد خودينداره منفى شدهاند جاى خود را به افكار مثبت مى دهند كه باعث ايجاد افكار مثبت و برداشت مثبت فرد از خود مى گردد. اين برداشت مثبت خوديند اره منفى فرد از خود را تعديل مى كند. در فرايند هنردرمانى نيز هنر باعث مىشود تا فرد به گونهاى متفاوت از فعاليتهاى

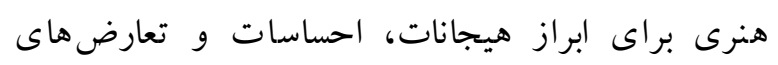

نتايج جدول شماره F نشان مى دهد كه تحليل كوواريانس و و $F=V / \Delta \Delta \Delta)(p=\cdot / \cdot)$ (p=•/·)

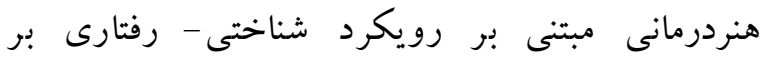
خودينداره و تن انكاره دختران نو جوان مبتلا به اختلال بدشكلى در مرحله بيخيرى تداوم داشته است.

\section{بحث و نتيجه كيرى}

هدف از انجام بثزوهش حاضر بررسى تأثير هنردرمانى

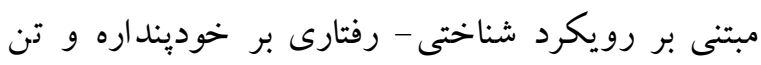

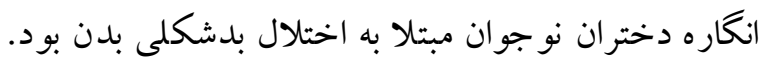
مداخله صورت گرفته باعث تغيير معنىدار خودينداره در نمونه يزووهش كرديد. اين يافته با يافته هاى بزوهششهاى

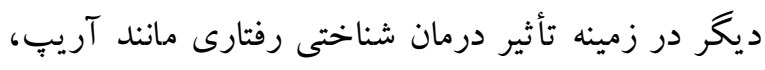
يوسف، جوسو، سليم و صمد (Y. Y) يا ئزوهشهايى كه اثربخشى هنر درمانى را نشان دادهاند مانند زارع زاده

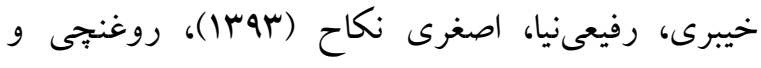
محمد (r|r. (Y) همخوان است. براى دركك تأثير گذارى هنردرمانى بر خودينداره ابتدا بايد ماهيت اختلال برر سى شده را مو رد تو جه قرار داد. در

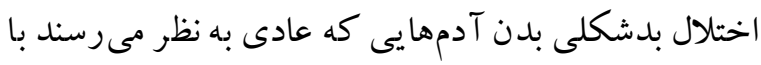
ديخران معاشرت نمى كنند يا كارهاى عادى خود را انجام نمى دهند جون مى ترسند ديخران به زشتى آنها بخندند. 
است؛ بنابر اين تو جه به اين شناختهاى منفى و تغيير آنها

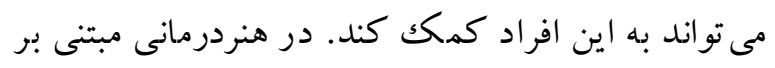
رويكرد شناختى - رفتارى همزمان با اينكه با استفاده از هنر درمانى به فرد كمكك مى شود تا هيجان و احساسات منفى خود را كه شايد تاكنون نتو انسته ابراز كند نشان دهد، شناخت ها و افكار منفى فرد در رابطه با بدنش نيز مورد توجه قرار مى گيرد و در فرآيند درمان اين شناختهاى منفى با شناختهاى منطقى تر و درست تر جايخز ين مى شود. جايخز ينى اين افكار با افكار منطقى تر

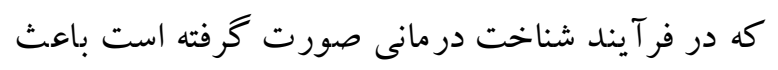
مىشود كه بهتدريج برداشت اين افراد از بدنشان مثبت تر

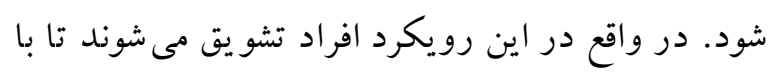
توجه به افكار خودآيند منفى و شناسايى تحريف ورداى درد شناختى و به جالش كشيدن آنها در ادامه با بازسازى بهى

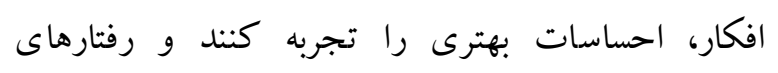
مناسب ترى از خود بروز دهند. نتايج به صورت كلى نشان از تأثير كذارى هنردرمانى مبتنى بر رويكرد شناختى -رفتارى دارد لذا درمانكران بالينى مى تواند از اصول هنردرمانى در درمان اين اختلال

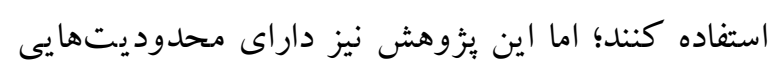

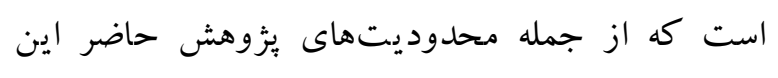
است كه نتايج قابل تعميم به ديخر نمونهها و ديخر اختلالها نيست. - التهاء

\section{سياسگزارى}

بدين وسيله مراتب سباس خود را از دانش آموزان دختر شهرستان اهواز و همجنين از مسئولين دانشگاه آزاد اسلامى جهت همكارى لازم را اعلام مىداريم.
درونى خود استفاده كند؛ بنابراين در فرآيند درمان تركيب هنر درمانى و شناخت درمانى باعث مى شود كه فرد شناخت بهترى از خود بيدا كند و خودينداره فرد بهبود مى يابد. اين امر همان نتيجهاى است كه در يزوهش حاضر در گروه آزمايش ديده شد و نشان دهنده تأثير هنر

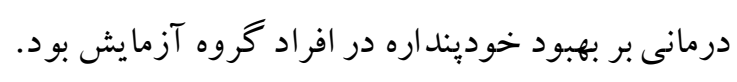
نتايج يزٔوهش همجنين نشان داد كه فرايند هنر درمانى مبتنى بر رويكرد شناختى - رفتارى در دختران نوجو ان

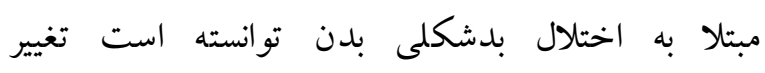

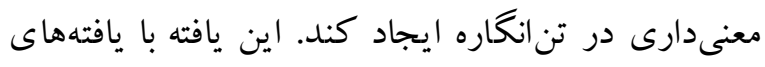

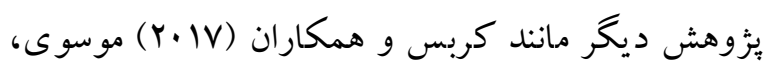

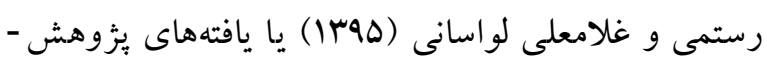
هايى كه اثربخشى هنر درمانى را نشان دادهاند مانند

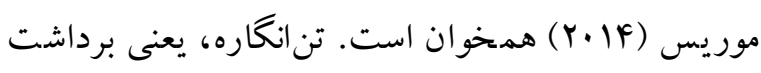
و تصور منحصربه فرد و درونى هر فرد از خود بيرونى يا

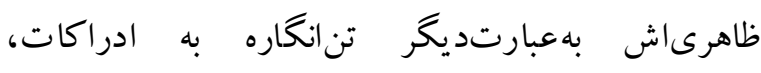
احساسات و افكار يكك شخص در مورد بدنش كفته مى شود و معمولاً به عنوان سازهاى متشكل از برآورد اندازه بدن، ارزيابى از جذابيت بدن و احساسات مربوط به اندازه و شكل بدن مفهوم سازى مىشود (رياحى،

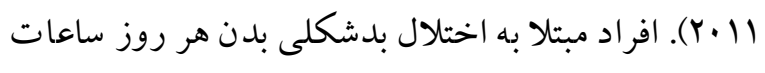
زيادى را صرف تفكر درباره نقص ادراكك شدهان مى كنند و اغلب درگير رفتارهاى تكرار شونده و وقت گير نظير مقايسه كردن، جّك كردن در آينه، مراقبت افراطى

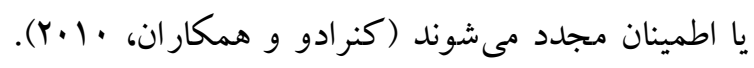

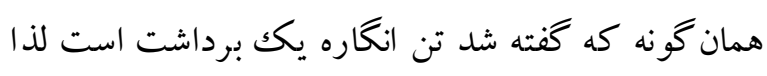
ذهنى است و فردى كه داراى تن انگًاره منفى از خود

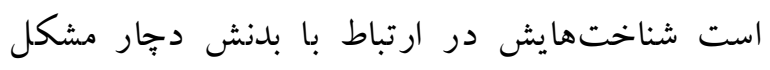




\section{Refrences:}

Arip, M.A; Yusooff, F.B Juso, A.J; Salim, S.S; \& Samad, N.A. (2011). The effectiveness of cognitive behavioral therapy (CBT) treatment group on self - concept among adolescents.International Journal of Humanities and social science, 1(8): 113- 122.

Barlow, DH; Durand, V. Mark .(2014). Abnormal Psychology An Integrative Approach Wadsworth Publishing Company

Buhlmann, U; Ghesmer, H; Mewes, R; Fama, JM; Wilhelm, S; Brahler, E, et al (2012). Updates on the prevalence of body dysmorphic disorder: Apopulation- based survey. Psychiatry Res, 178(1):171-175.

Conrado, LA; Hounie, AG; Diniz, JB, Fossaluza, V; Torres, AR; Miguel, EC, et al (2010). Body dysmorphic disorder among dermatologic patients:Prevalence and clinical features. J Am Acad Dermatol, 63(2):235-43.

Dunn, N; Shields, N; Taylor, NF; \& Dodd, KJ. (2010). Comparing the self concept of children with cerebral palsy to the perceptions of their parents. Disability and Rehabilitation, 56:218226.

Edwards, D. (2004). Art therapy. creative therapies in practice. Thousand Oaks, CA.

Freeth, R. (2007). Humanizing psychiatry and mental health care: the challenge of the personcentered approach United Kingdom: Radcliffe publishing Ltd.

Khadivi, T.N; \& Vakili Mafakheri, A. (2011). The relationship between achievement motivation, locous of control, self-image and academic achievement in students of Tabriz Joumal of Educacational Sciences, 4(13): 45-66. (Persian)

Kodositabar, M; Sadri, M; Zanily, Z; Ibrahim, Z; \& Sahrawi, E. (2012). Relationship between motor proficiency and self concept in girl students 11- 14 ages. Annals of Biological Research, 4(6): 276- 280.

Kolli, I; \& Martin, A. (2014). Body - related cognitions, affect and post- event processing in body dysmorphic disorder. Journal of Behavior therapy and Experimental Psychiatry, 144 151.

Krebs, G; Cru, LF; Monzani, B; Bowyer, L; Anson, M; Cadman, J; Heyman, I; Turner, C; Veale, D;\& Mataix-Cols, D. (2017). Long- term outcomes of cognitive-behavioral therapy for adolescent body dysmorphic disorder. J Behavior therapy.

Mataix- Cols, D; Cnuz L; Isomura, K; Anson, M; Turner, C; Monzani, B; Cadman, J; Bowyer, L; Heyman, I; Veale, D;\& Krebs, G. (2015). Apilot randomized controlled trial of cognitivebehavioral therapy for adolescents with body dysmorphic disorder. Joumal of the American Academi of Child \& Adolescent Psychiatry, 54(11):895-904.

Mirfakhr rajai, N. (2015).The impact of art in design of child environment in respect to creativity development and mental health promotion. ICAUCAE, Future Horizons \& Retrospect.

Morris, F.J. (2014). Should art be integrated into cognitive behavioral therapy for anxiety disorders?. The Arts in Psychotherapy, 41(4): 343-352.

Otto, MW; Wilhelm, S; Cohen, LS; \& Harlow, BI.(2001). Prevalence of body dysmorphic disorder in a community sample of women. A mJ Psychiatry, 158(12):2061-3.

Pastorino, EE; \& Doyle- Portillo, S.M. (2013). What Is Psychology?: Essentials. Belmont, CA: Wadsworth.

Raghibi, M; \& Minakhani, G. (2012). Body management and its relation with body image and self concept. Knowledge \& Research in Applied Psychology, 12(46): 72-81.

Riahi, ME. (2011). Gender differences in satisfaction of body image. Journal Women in Development\& Politics, 3(9)-25-32. (Full text in Persian).

Roghanchi, M; Mohamad, A, et al. (2013). The effect of integrating rational emotive behavior therapy and art therapy on self esteem and resilience. Arts Psychother, 40(2): 179- 80.

Sadock BJ; Sadock VA; \& RuizP. (2015).Synopsis of Psychiatry. Vol 1. Philadelphia: Wolters Kluwer:;11:473-5. 
Sanchez, F.J.P;\& Roda, M.D.S. (2007). Relationship between self-concept and academic achievement in primary students. Almeria: Spain:97.

Thomton, B; Ryckman, RM; \& Gold, JA. (2013). Competitive orientations and woman's acceptance of cosmetic surgery. Psychology, 4(1).67-72. 